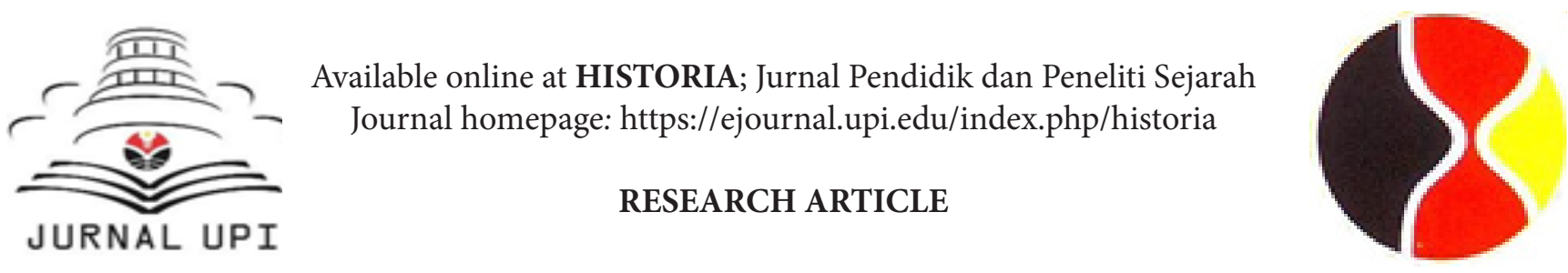

\title{
SOEKARNO, NASAKOM, DAN BUKU DI BAWAH BENDERA REVOLUSI SEBAGAI MATERI AJAR PELAJARAN SEJARAH SMA
}

\author{
Ema Agustina \\ Jurusan Pendidikan Sejarah, FKIP Universitas PGRI Palembang, \\ emaagustina@upi.edu
}

To cite this article: Agustina, E. (2020). Soekarno, Nasakom, dan buku di bawah bendera revolusi sebagai materi ajar pelajaran sejarah sma. HISTORIA: Jurnal Pendidik dan Peneliti Sejarah, 3(1), 57-64. https://doi.org/10.17509/ historia.v3i1.20908

Naskah diterima : 5 November 2019, Naskah direvisi : 26 November 2019, Naskah disetujui : 30 Desember 2019

\begin{abstract}
The book entitled "Di Bawah Bendera Revolusi" is Sukarno's original idea. He wrote an article about three concepts of pre independence movement namely ideology of Nationalism, Islamism, and Marxism which were then known as NASAKOM in 1926. Soekarno only took the essential elements of Marxism,that was his method of thinking which was called historical materialism to be combined with two other elements which contained aspect of modernity needed by Indonesian citizen. From the excerpt of Soekarno's opinion about Nationalism, Islamism, and Marxism, it seems that he tried to look for compatible aspects from those three ideologies became power to achieve unity. Soekarno then made this idea as struggle device to establish NKRI. This should be discussed deeper in any history subjects especially for Senior high school. Soekarno's thought about NASAKOM which was written in many Senior High School textbooks was only discussed partly so it can lead to the misinterpretation about Soekarno and his thought.
\end{abstract}

Keywords: History; Islamism; Nationalism; Marxism; Teaching Materials.

\begin{abstract}
Abstrak
Buku dengan judul "Di Bawah Bendera Revolusi" merupakan buah pemikiran dari Soekarno. Ideologi nasionalisme, islamisme, dan marxisme yang kemudian dikenal dengan NASAKOM merupakan tiga konsep gerakan pra kemerdekaan yang ditulis oleh Soekarno pada tahun 1962. Hanya elemen yang terpenting dari marxisme yang diambil Soekarno yaitu metode berpikirnya yang kemudian disebut dengan historis materialisme dan diramu dengan dua elemen yang mengandung aspek modernitas. Hal tersebut dianggap Soekarno diperlukan bagi bangsa Indonesia. Dari beberapa kutipan pendapat Soekarno tentang konsep nasionalisme, islamisme, dan marxisme dapat diketahui bahwa ia berusaha mencari titik temu dari ketiga ideologi tersebut agar menjadi suatu kekuatan dalam mencapai persatuan. Ide ini kemudian dijadikan Soekarno sebagai alat perjuangan untuk mendirikan NKRI. Hal tersebut sebaiknya dikupas cukup mendalam pada pembelajaran sejarah khususnya di Sekolah Menengah Atas. Pemikiran Soekarno tentang nasakom yang tercantum pada buku teks sejarah SMA hanya sekilas sehingga dapat menimbulkan salah tafsir tentang Soekarno dan pemikirannya.
\end{abstract}

Kata Kunci: Islamisme; Materi Ajar; Marxisme; Nasionalisme; Sejarah. 


\section{PENDAHULUAN}

Perkembangan Indonesia sebagai suatu bangsa tidak terlepas dari dinamika mengenai sebuah ideologi. Ideologi yang berkembang pada masa pergerakan dan bahkan terus berkembang hingga pasca kemerdekaan. Dalam beberapa periode, menurut Feith dan Castles (1988) terdapat beberapa ideologi yang kemudian berkembang di Indonesia, yakni tradisionalisme Jawa, Islam, nasionalisme radikal, komunisme, dan sosialisme demokratis. Ideologi tradisionalisme Jawa itu sendiri tidak terlalu dianggap memiliki pengaruh terutama dalam pemikiran politik, tapi faktanya ada banyak organisasi yang justru dipengaruhi oleh nilai-nilai tradisionalisme Jawa.

Sementara itu, Islam memberikan dampak dan pengaruh yang cukup kuat khususnya pada partai politik seperti halnya NU dan Masyumi. Sedangkan nasionalisme radikal juga cukup berpengaruh dalam pembentukan PNI. Kemudian komunisme memiliki peran atas lahirnya PKI. Selain itu, demokratis juga dianggap berhasil dalam menginspirasi dan melahirkan kelompok politik besar seperti PNI dan Masyumi. Sedangkan aliran sosialisme demokratis lebih meletakkan perhatian partai untuk kebebasan individu, keterbukaan terhadap perkembangan arus intelektual dunia dan menolak chauvinisme.

Ketika pergerakan Indonesia mulai diwarnai oleh perpecahan yang pada waktu itu Soekarno hanya sebagai pengamat dari berbagai peristiwa dan belum mengikutsertakan dirinya dalam aktivitas politik. Ia melakukan pengamatan terhadap perpecahan yang terjadi pada saat itu dan hal tersebut bersamaan pula dengan minat bacaannya tentang sejarah sosial demokrasi Eropa yang kemudian memberikan kesan bahwa betapa jahatnya pertengkaran setiap fraksi dan keharusan akan terwujudnya persatuan (Kasenda, 2011, hlm. 11).

Algemenee Studie Club adalah kelompok studi yang berdiri di Bandung pada tahun 1962 merupakan titik tolak bagi Soekarno yang kemudian membawa ia terjun ke aktivitas pergerakan dan politik. Kelompok studi ini menerbitkan majalahnya sendiri yakni Suluh Indonesia Muda. Di majalah tersebut, Soekarno menuangkan pikiran dan gagasannya dengan tulisan. Pada saat yang sama yakni tahun 1926 Soekarno menerbitkan artikel terkenal yaitu konsep NASAKOM "Nasionalisme, Islamisme, dan Marxisme" yang kemudian dimuat dalam Suluh Indonesia Muda (Suyanto dalam Sjamsuddin, 1993, hlm. 48).

Karangan Soekarno yang berjudul nasionalisme, islamisme, dan marxisme kemudian dimuat berturutturut hingga tiga periode pernerbitan. Karangannya memuat tentang pernyataan dan gagasan Soekarno mengenai nasionalisme sekuler baru. Hal tersebut sebagai bentuk dari keprihatinan dan sekaligus menawarkan solusi bagi pergerakan Indonesia yang pada saat itu masih terkotak-kotak karena fokus dengan ideologi masingmasing. Hal ini juga tidak jarang dapat menimbulkan benturan dan konflik antar penganut ideologi; penganut nasionalis, penganut islam, dan penganut komunis.

Konsep ideologi nasakom yang menjadi ciri khas Soekarno ini terdapat dalam materi ajar di Sekolah Menengah Atas kelas XI pada semester kedua namun pembahasannya sangat minim sehingga dapat menimbulkan perspektif yang beragam. Kemudian terdapat pula pembahasan tentang pertentangan antar ideologi pada kelas XII semester pertama. Dari pembahasan-pembahasan tersebut tidak terlalu rinci dan mendalam pembahasan tentang nasakom itu sendiri. Oleh karena itu, meskipun nasakom merupakan konsep yang ditawarkan Soekarno namun mengalami kegagalan dalam implementasinya tetap saja materi tentang nasakom ini sangat perlu dipahami siswa terutama siswa Sekolah Menengah Atas yang sudah mampu dalam berpikir kritis terhadap fakta dan peristiwa sejarah.

Kajian yang berkaitan dengan ideologi nasakom sebelumnya telah banyak dilakukan, seperti penelitian yang dilaksanakan oleh B. Merita Pamudyaningtyas (2011) tentang "Gagasan Soekarno tentang Nasakom dan Sosialisasinya pada Tahun 1960-1965". Demikian pula penelitian dari Arpandi A. Cenne (2016) yang mengusung tentang "Pemikiran Politik Soekarno tentang Nasakom Rentang 1959-1966”. Bahkan M. Akbar Yanlua (2017) melakukan kajian tentang "Studi Perbandingan Pemikiran Nasakom Bung Karno dan Piagam Madinah dalam Konteks Indonesia". Kemudian penelitian oleh Lingga Winata dan Sri Mastuti Purwaningsih (2017) mengenai "Nasakom sebagai Ideologi Negara Tahun 1959-1965" dengan salah satu hasil dari penelitiannya adalah tentang tiga fungsi nasakom sebagai ideologi.

Pertama, nasakom dipergunakan sebagai hal yang mengimbangi kekuatan politik serta menjaga terjadinya kudeta yang berkaitan dengan posisi Soekarno. Kedua, sebagai ideologi yang diharapkan mampu menjaga integritas dan persatuan bangsa. Ketiga, fungsi legimitasi, nasakom dilegimitasikan agar kekuasaan Soekarno terimplementasi dalam kehidupan berbangsa dan bernegara. Beberapa penelitian dengan berbagai sudut pandang diatas membahas secara mendalam tentang gagasan Soekarno tersebut namun karena penelitian tersebut dilakukan bukan dalam ruang lingkup sekolah terlebih dalam pembalajaran sejarah di Sekolah Menengah Atas maka dalam kajian ini akan berfokus pada materi nasakom dalam buku di Bawah Bendera 
HISTORIA: Jurnal Pendidik dan Peneliti Sejarah, 3(1), 57-64. DOI: https://doi.org/10.17509/historia.v3i1.20908.

Revolusi sebagai materi ajar pada mata pelajaran sejarah di SMA. Aspek yang telah dikaji pada penelitian sebelumnya memperkaya materi tentang nasakom sebagai buah pemikiran Soekarno meskipun pada kajian ini fokus dengan materi nasakom yang ditulis sendiri oleh Soekarno.

Pembelajaran sejarah khususnya pada tingkat Sekolah Menengah tidak terlepas dari peranan buku teks. Bahkan bisa dikatakan guru masih sangat terpacu dan bertumpu pada buku teks. Padahal menurut Hasan (2012, hlm. 87), bahwa dalam penerapan pembelajaran sejarah pada kurikulum 2013 tidak menuntut guru untuk hanya terpaku pada buku teks saja, melainkan guru ataupun siswa harus berperan aktif dalam mengumpulkan sumber informasi tidak hanya dari buku teks namun bisa juga dari beberapa sumber lainnya. Guru dan siswa berperan aktif dalam mengumpulkan informasi, kemudian informasi tersebut diolah, merekonstruksi data ataupun fakta serta nilai, menampilkan hasil rekonstruksi dan memproses pengembangan nilai-nilai dari fakta tersebut, menumbuhkembangkan nilai-nilai budaya dan karakter pada diri mereka melalui berbagai macam kegiatan belajar yang terjadi baik di kelas, di sekolah, maupun tugas yang terdapat di luar sekolah.

Artikel yang telah ditulis oleh Soekarno tentang gagasan ideologi nasionalisme, islamisme, dan marxisme yang sebelumnya dimuat dalam surat kabar Suluh Indonesia Muda tahun 1926 kemudian buah pikiran tersebut juga dikumpulkan dalam buku dengan judul "Di Bawah Bendera Revolusi” jilid pertama, ini juga bisa dijadikan sebagai sumber informasi yang valid dan dapat dijadikan materi pembelajaran sejarah di Sekolah Menengah Atas.

\section{Nasionalisme, Islamisme dan Marxisme pada Buku di Bawah Bendera Revolusi}

Buku dengan judul "Di Bawah Bendera Revolusi" merupakan kumpulan pikiran dan gagasan Soekarno yang dituangkan dalam tulisan pada saat proklamasi kemerdekaan Indonesia belum terlaksana. Cita-cita dalam membangun bangsa Indonesia yang merdeka dan berdaulat dari seorang proklamator tersirat dalam ide atau gagasan yang dirangkum dalam kumpulan tulisannya. Dalam buku ini pula telah terlihat jelas bagaimana Soekarno menjunjung tinggi rasa persatuan. Dari beberapa tulisan Soekarno, sebagian pernah dimuat oleh media massa diantaranya Suluh Indonesia Muda dan Fikiran Rakyat, akan tetapi terdapat pula artikel yang belum pernah dipublikasikan dan kumpulan tulisan tersebut disusun secara sistematis dan kronologis. Hal tersebut dilakukan dengan tujuan agar pembaca lebih dimudahkan dalam mengikuti dan memahami perkembangan pemikiran Soekarno. Terdapat 61 artikel yang dimuat dalam buku yang ditulis oeh Soekarno ini. Karena alasan politis pada masa orde baru yakni masa kepemimpinan Soeharto, buku gubahan Soekarno menjadi bagian dari buku yang terlarang. Hal ini terjadi karena buku tersebut diindikasi dapat membangkitkan ideologi yang terlarang, yaitu ideologi komunis. Akan tetapi, larangan tersebut sudah tidak berlaku setelah runtuhnya kepemimpinan Soeharto dan buku Soekarno justri dicetak kembali pada tahun 2014.

Soekarno menyatakan bahwa begitu tragisnya orang-orang Eropa menjajah Asia dan mengeksploitasi kekayaan di Asia untuk dijadikan sumber-sumber kekayaan di negara asal mereka. Meskipun begitu Spirit of Asia masih kekal, roh Asia tetap akan hidup seperti layaknya api yang tidak padam. Tragedi inilah yang akan menjadi modal awal bagi pergerakan rakyat Indonesia, meskipun maksud dan tujuannya sama, yakni mencapai persatuan namun tetap memiliki tiga sifat, diantaranya ialah nasionalis, islamis dan marxistis.

Dengan mempelajari dan mencari hubungan dari ketiga sifat tersebut, membuktikan bahwa dalam suatu negeri jajahan tidak aka nada gunanya jika berseteru hanya karena perbedaan ideologis. Hal ini membuktikan juga, jika dari tiga gelombang tersebut mampu untuk bekerja sama menjadi satu gelombang yang sangat besar dan sangat kuat, dan menjadi sebuah ombak besar yang tidak bisa ditahan terjangannya. Perkara berhasil ataupun tidak, yang terpenting adalah kita telah menjalankan kewajiban dan usaha yang berat dan mulia, dan bukan juga kita yang menentukannya. Kita juga tidak boleh berputus asa dalam berupaya dan berusaha untuk kewajiban dalam mempersatukan gelombang perbedaan tersebut. Karena yang mestinya diyakini adalah persatuan dengan tujuan nantinya dapat mewujudkan terkabulnya impian yang besar yaitu Indonesia Merdeka (Soekarno, 1964).

Nasakom merupakan jiwa yang berisikan tiga kekuatan yang menurut Soekarno dapat berdiri tegak bersama menjadi satu kesatuan untuk mencapai persatuan. Nasionalisme yang pada hakikatnya memiliki keinginan untuk hidup menjadi satu golongan dan satu bangsa. Bukannya mengharapkan dan mengharuskan yang nasionalis berubah menjadi lebih islamis atau condong ke marxis, bukan pula menjadikan mereka yang marxis dan memiliki ideologi islamis itu menjadi berbalik ke nasionalis, namun sebenarnya yang ingin dicapai ialah kerukunan dan persatuan dari ketiga golongan tersebut.

Sang proklamor percaya akan pepatah "rukun membikin sentausa" bahwa sesungguhnya banyak jalan menuju arah persatuan, hanya saja seberapa kuat untuk 
melawan semua perbedaan dan besarnya keseganan dari semua pihak yang berkaitan dalam pergerakan tersebut (Soekarno, 1964).

Nasionalis yang sangat sejati adalah nasionalis yang memiliki cinta yang besar terhadap tanah airnya dan bersendi dan berakar pada pengetahuan yang luas atas susunan dunia dan segala riwayatnya bukan timbul karena semata-mata dari kesombongan dan keangkuhan bangsa belaka. Nasionalis tidak berarti ia harus chauvinis dan menolak pemahaman yang cenderung sempit yang justru dapat memicu perpecahan. Nasionalis yang bukan hanya hasil adaptasi dari nasionalisme Barat namun juga tumbuh dari rasa cinta terhadap manusia dan juga kemanusiaan.

Nasionalisme yang berorientasi ke-Timur-an jugalah yang mengilhami seorang Mahatma Gandhi, C.R.Das, Arabindo Ghose, Mustafa Kamil, Dr. Sun Yat Sen. Serupa dengan itu, Indonesia terilhami bahwa nasionalisme ke-Timur-an adalah sesungguhnya sangat berbeda dan justru menolak pada nasionalisme keBarat-an yang berorientasi pada hal yang duniawi seperti yang dikatakan oleh Bipin Chandra Pal. Bahwasanya hanya ideologi nasionalis ke-Timur-an yang sejatinya yang pantas bagi nasionalis timur. Nasionalisme Eropa ataupun nasionalisme menurut C.R.Das yang justru memiliki sifat saling serang, suatu nasionalisme yang cenderung mengejar kepentingan mereka sendiri, mengejar keuntungan ataupun kerugian, paham nasionalis yang seperti inilah yang nantinya dapat membinasakan (Soekarno, 1964).

Soekarno mengakui bahwa ia memperdalam masalah nasionalisme dan juga masalah ekonomi dari Sun Yat Sen yang merupakan tokoh gerakan nasionalis dari China yang kemudian menerbitkan buku yang berjudul San Min Chu-I. Selain itu, ia juga membaca tentang Karl Marx dan Thomas Jefferson. Mungkin karena itu juga ia pada akhirnya harus menghadapi sasaran dari salahnya pengertian dan persepsi. Seperti yang ia kemukakan dalam buku Di Bawah Bendera Revolusi (hlm. 175):

"pernah saja terangkan, bagaimana seorang pemimpin, Jean Jaures jang bukan komunis, djuga menghendaki demokrasi politk dan demokrasi ekonomi. Dan dalam karangan saja dulu sudah saja katakana pula, bahwa Dr. Sun Yat Sen mentjela demokrasi yang demikian itu."

Selanjutnya mengenai konsep islamis menurut Soekarno, konsep Islam yang sesungguhnya justru tidak mengandung azas yang anti akan nasionalis, begitupun anti sosialis tentunya ia juga tidak akan bertabiat seperti itu. Apabila kaum islamis memusuhi paham nasionalis yang dianggap memiliki keluasan budinya selanjutnya ia juga tidak sepaham dengan marxisme yang sebenarnya maka saat itu juga kaum islamis justru tidak mampu berpijak di Sirothol Mustaqim dan mereka juga tidak akan bisa menyelamatkan Islam dari kenistaan maupun kerusakan. Sebenarnya Soekarno tidak pernah menyatakan bahwa Islam itu berorientasi pada materialism, bahkan ia mengungkapkan bahwa Islam itu bahkan melebihi bangsa itu sendiri. Menurutnya Islam yang sejati justru memiliki tabiat dan nilai sosialistis kemudian menjadikan nasionalis sebagai suatu kewajiban. Islam yang sebenarnya akan mengharuskan bagi para pemeluknya untuk mencintai dan bekerja keras untuk negeri yang ia tinggali. Selain itu, ia juga wajib mencintai dan bekerja keras untuk rakyat dimana ia hidup dan menetap (Soekarno, 1964).

Seyid Djamaluddin El Afghani telah banyak mengkhutbahkan tentang paham nasionalilsme dan paham patriotisme, kemudian disebutkan "fanatisme" sebagai musuhnya. Ia disebut sebagai pendekar Pan Islamisme yang banyak berbicara tentang rasa hormat terhadap diri sendiri, sifat yang budi luhur, sikap menghormati suatu bangsa dan dianggap musuhnya sebagai chauvinism. Dimana-mana, terutama di Mesir ia disebut sebagai "Bapak Nasionalisme Mesir". Selain Seyid Djamaluddin, terdapat pula beberapa tokoh yang juga berperan dalam menanamkan rasa nasionalisme dan cinta terhadap bangsa yakni Arabi Pasha, Ali Pasha, Mohammad Ali, Mustofa Kamil, Ahmad Bey Agayeff, Shaukat Ali, dan Mohammad Farid Bey. Selain itu, mereka juga disebut sebagai Panglima Islam yang mendengungkan tentang rasa cinta akan bangasa. Pemimpin-pemimpin yang islamis hendaknya dapat dijadikan teladan bagi islamis yang sangat fanatik dan cenderung memiliki pemikiran yang kurang terbuka sehingga mereka enggan untuk merapatkan diri pada bangsa yang memiliki gerakan yang nasionalis (Soekarno, 1964).

Demikian pula Soekarno menyakini bahwa kaum islamis itu juga dapat merapat diri dengan mereka yang marxis, meskipun pada dasarnya dua pihak ini jelas memiliki landasan yang sangat berbeda. Sungguh memilukan tatkala adanya perpecahan dan permusuhan dikarenakan perebedaan diantara kelompok marxis dan kelompok islamis. Timbulnya permusuhan dari para masrxis dan islamis merupakan bukti bahwa pergerakan akhirnya terbelah dan saling memerangi satu sama lainnya.

Pertarungan antar saudara ini juga yang membuat kekuatan pergerakan menjadi terbuang sia-sia, yang mestinya kekuatan pergerakan bangsa makin lama makin kuat. Tidak ada halangan yang krusial bagi persahabatan kaum marxis dan muslim. Sejatinya 
HISTORIA: Jurnal Pendidik dan Peneliti Sejarah, 3(1), 57-64. DOI: https://doi.org/10.17509/historia.v3i1.20908.

seorang islamisme seharusnya tertanam juga nilai-nilai sosialistis. Sosialis itu sendiri tidak berarti bermakna marxistis dan sosialisme Islam sangat berbeda dengan azas marxisme. Sosialisme Islam cenderung berazas spiritualisme sedangkan sosialisme marxisme lebih menjurus pada hal yang berazas materialism. Meskipun demikian, sebagai kebutuhan untuk mencapai persatuan bahwa seorang islamis tentunya adalah ia juga adalah orang yang sosialistis maka hal tersebut cukup untuk menjadi suatu bukti bahwa kedua hal yang berbeda dapat disatukan persepsinya (Soekarno, 1964).

Mereka yang islamis tentunya harus mengingat bahwa kapitasime merupakan musuh bersama bagi marxisme dan kaum islamis. Terdapat pula teori yang disusun oleh Karl Marx dan Friedrich Engels yang dikenal dengan teori meerwaarde. Hal ini untuk menjelaskan tentang asal muasal terjadinya kapitalisme. Makna dari meerwaarde ialah kondisi dimana hasil pekerjaan orang lain yang dimakan dan tidak ada pembagian keuntungan untuk kaum buruh yang pada dasarnya merekalah yang bekerja dan mencari keuntungan tersebut. Jika meerwaarde pada paham marxisme maka dalam Islam dikenal dengan riba. Pokok utama dari semua peraturan yang kaitannya dengan kapitalis mengacu pada konsep meerwaarde tadi. Untuk memerangi kapitalisme maka kaum marxisme memerangi meerwaarde hingga ke akarakarnya. Oleh karena itu, menurut Soeakarno bahwa tidak layak untuk islamis sejati memusuhi paham marxis yang memerangi peraturan meerwaarde dimana Islam juga sebenarnya memerangi hal tersebut (Soekarno, 1964).

Pergerakan marxistis di Indonesia pada saat itu tidak berhaluan dengan nasionalistis dan ingkar pula terhadap gerakan yang berazaskan ke-Islaman. Bahkan beberapa waktu sebelumnya, perbedaaan tersebut menjadi pemantik terjadinya suatu perpecahan. Tinggalkanlah nasionalisme, hilangkanlah politik cinta tanah air, kuburkanlah politik keagamaan, seperti itulah konflik perbedaan yang terjadi. Sebaliknya, nasionalistis dan islamis juga tiada henti mencaci pihak marxis, dianggap pergerakan yang "mungkir" akan Tuhan. Satu sama lain saling berselisih, saling tuduh menuduh, tidak sepahaman dan saling tidak mendengarkan. Namun berbeda dengan marxis yang terbaharukan, ia cenderung dapat beriringan dengan nasionalis begitupun dengan islamis yang terdapat di Asia. Strategi marxisme baru justru membantu dan mendukung pergerakan-pergerakan yang dilakukan oleh nasionalis dan islamis dengan sepenuhnya. Marxis yang statis dan tidak terbuka dengan perkembangan zaman serta tidak memahami tentang taktik yang telah berubah maka mereka akan tetap bermusuhan dengan pergerakan nasionalis ataupun islamis di Asia (Soekarno, 1964).

Adapun teori marxisme telah mengalami perubahan dan memang seharusnya begitu, hal ini dikarenakan Marx dan Engels bukan merupakan "nabi-nabi" yang membuat semua aturan yang dapat dipakai untuk segala zaman. Teori-teori tersebut mesti diperbaharui seiring dengan perkembangan zaman yang sudah mengalami banyak perubahan. Taktik dan strategi yang telah dirubah kemudian terdapat pula perubahan teori, hal inilah yang pada akhirnya menjadi alasan bagi kaum marxis mendukung serta menyongkong pergerakan nasional secara bersungguh-sungguh. Mereka memahami bahwa apabila pergerakan marxis yang ada di Asia maka sudah semestinya ia tidak sama seperti pergerakan marxis yang ada di Eropa dan sudah seharusnya jika bersatu dalam melakukan perlawan bagi mereka yang feodalisme.

Di negara-negara Asia, kaum buruh memiliki keleluasaan untuk menjalan berbagai pergerakan sosialistis. Oleh karena itu, diperlukan negara yang merdeka dan kaum itu juga dibutuhkan untuk mempunya national autonomie (otonomi nasional). Menurut Otto Bauer, otonomi ini merupakan hal yang harus menjadi tujuan bagi perjuangan proletary karena hal tersebut bagian yang sangat penting bagi politik mereka. Maka dari itu, otonomi nasional menjadi hal yang utama untuk diperjuangan oleh pergerakan buruh yang ada di Asia (Soekarno, 1964).

Tumbuhnya rasa nasionalisme dihati para buruh di Indonesia juga dipengaruhi oleh pergerakan marxis, hal ini dikarenakan modal yang tertanam di Indonesia sebagian besar bersumber dari modal asing. Pemimpinpemimpin marxis di negeri Tiongkok dapat dijadikan teladan dimana ia menyokong usaha kaum nasionalis karena mereka menyadari bahwa yang pertamatama dibutuhkan adalah persatuan dan kemerdekaan nasional. Begitu juga halnya bahwa tidak sepantasnya kaum marxis itu bermusuhan dengan pergerakan islamis, tidak pantas memerangi pergerakan yang pada dasarnya mereka sama-sama bersikap anti kapitalisme, anti riba, dan anti meerwaarde. Tidak sepantasnya pula pergerakan memerangi pergerakan lainnya yang dengan jelas ingin mencapai kemerdekaaan, persamaan, persaudaraan, mengejar nationale autonomie (Soekarno, 1964).

Elemen terpenting yang diserap oleh Soekarno dari marxisme adalah metode berpikirnya (historis materialism), hal ini kemudian diramu bersamaan dengan elemen lainnya yang memiliki kandungan modernitas dan sangat dibutuhkan oleh Indonesia yakni nasionalisme maupun demokrasi. Dengan ini Soekarno mewujudkan marhaenisme. Menurutnya, marhaernisme 
adalah marxisme yang dapat diimplementasikan dan dianggap cocok dengan kondisi dan situasi yang ada di Indonesia. Bukan hanya menerapkan marxisme, Soekarno juga memiliki kreatifitas dan keberanian dalam merevisi marxis untuk disesuaikan dengan kondisi Indonesia. Salah satu yang ingin ia wujudkan ialah mengelakkan dominannya peran kaum proletar yang kemudian digantikan oleh marhaen. Berbeda dengan proletar yang mampu untuk mengadakan alatalat produksi meskipun dalam skala kecil, marhaen merupakan kaum yang cukup sulit untuk memiliki hal tersebut karena mereka adalah kaum yang melarat di Indonesia (Soekarno, 1964).

Perjuangan kelas dan strata yang merupakan bagian dari teori marxis adalah salah satu teori yang tidak diaplikasikan oleh Soekarno. Hal tersebut dikarenakan ia berpandangan bahwa persatuan dari berbagai golongan itulah yang sesungguhnya dibutuhkan oleh Indonesia dan hal ini dapat dijadikan modal dalam menyingkirkan kolonialisme yang telah berserikat dengan imperialism dan kapitalisme. Marx yang tidak suka akan nasionalisme sangat berbeda dengan Soekarno karena baginya nasionalisme merupakan bagian yang penting dalam perlawanan terhadap kapitalisme dan Imperialisme yang terdapat di Indonesia. Meskipun begitu, ia adalah pengikut tradisi pemikirna Marxis, ini dikarenakan oleh cara berpikirnya memperlihatkan ciri dari cara berpikir tersebut seperti caranya dalam melihat sesuatu dengan titik pandang cara produksi (mode of production). Memiliki pandangan yang maju ke depan merupakan bagian dari marhaenisme. Marhaenisme adalah antithesis dari imperialisme yang mempratikan keserakahan dalam menguras sumber daya alam dan kekayaan di Indonesia (Soekarno, 1964).

Dengan perjalanan yang tidak begitu sempurna namun Soekarno tetap mencoba untuk menunjukkan bukti bahwa ketiga paham Nasakom tersebut dapat berjalan beriringan di negeri jajahan, pada beberapa bagian ia dapat salingn menutupi satu sama lainnya. Dengan jalan yang tidak mudah, bisa membuktikan bahwa hal tersebut bisa dijadikan teladan bagi pemimpin di negeri lain. Soekarno dengan keyakinan teguh dengan terang benderang menampakkan citacita untuk menjadi satu kesatuan. Ia juga yakin jika pemimpin-pemimpin besar yang ada di Indonesia sadar akan pentingnya persatuan. Karena dengan persatuan itulah dapat membawa Indonesia ke arah kebesaran dan kemerdekaan. Meskipun terdapat perbedaan dalam pemikiran, kemauan dari masing-masing pihak namun ia menunjukkan bahwa persatuan dapat terwujud (Soekarno, 1964).

\section{Nasionalisme, Islamisme dan Marxisme pada Materi Ajar di Sekolah Menengah Atas}

Daricuplikan-cuplikan pendapatnyayangberkenaan dengan nasionalisme, islamisme, dan marxisme menunjukkan bahwa Soekarno berusaha mencari titik temu agar ketiga paham tersebut dapat diaplikasikan dengan positif. Meskipun jika ditinjau dengan lebih dalam titik-titik tersebut tidaklah didasarkan atas alasan yang cukup kuat. Ia berusaha menyatukan dalam suatu "common denominator" dan menghasilkan kekuatan. Tindakan tersebut merupakan pencerminan dari sifat sinkretisme Jawa yaitu cara menyatukan hal-hal yang berbeda-beda dalam suatu wadah (Dahm, 1969).

Konsep sinkretisme ketiga ideologi tersebut pada dasarnya berangkat dari pertentangannya terhadap kapitalisme dan imperalisme. Kebenciannya terhadap kapitalisme terlihat dari kritiknya, menurut Soekarno (2001) dalam buku Indonesia menggugat, kapitalisme adalah:

“...sistem pergaulan hidup yang timbul dari cara produksi yang memisahkan kaum buruh dari alat-alat produksi,kapitalisme timbul dari cara produksi yang tidak sampai ke tangan kaum buruh melainkan jatuh di dalam tangan kaum majikan. Kapitalisme, oleh karenanya pula menyebabkan akumulasi kapital, konsentrasi kpaital, sentralisasi kapital, Kapitaslisme mempunyai arah kepada verelending...(kemiskinan)."

Soekarno tidak sampai menjadi seorang komunis meskipun ia sangat anti kapitalis. Hal ini ia ungkapkan dalam beberapa kesempatan: "Dalam bidang politik, Soekarno adalah nasionalis. Dalam bidang ideology, aku menjadi sosialis. Aku katakan, aku bukanlah komunis. Aku seorang sosialis. Aku seorang kiri”. Bagi Soekarno, orang-orang kiri sebenarnya adalah orang yang justru memiliki kemauan agar terjadi perubahan dalam kekuasaan yang dikendalikan oleh imperialis dan kapitalis. Nasionalise hendaknya diikuti dengan keadilan sosial, karena tanpa itu maka ia menjadi bukan apaapa dan nihil semata. Ia juga mengungkapkan bahwa sosialisme dengan Declaration of Independence-nya AS dapat dicari dan diambil persamaannya. Persamaan pada sisi spiritual antara Islam dan Kristen kemudian persamaan ilmiah dari Karl Marx, persamaan tersebut menurut Soekarno dapat diadopsi. Setelah itu dapat diramu dengan memasukkan unsur gotong royong yang berperan sebagai jiwa ideologi. Dari hasil ramuan tersebut maka dapat melahirkan sosialisme Indonesia (Adams, 2018).

Fakta tentang Soekarno dan pemikirannya seperti yang terurai di atas tidak sepenuhnya didapatkan di sekolah. Padahal hal tersebut sebaiknya tersampaikan kita

HISTORIA: Jurnal Pendidik dan Peneliti Sejarah, p-issn:2620-4789 | e-issn:2615-7993 
HISTORIA: Jurnal Pendidik dan Peneliti Sejarah, 3(1), 57-64. DOI: https://doi.org/10.17509/historia.v3i1.20908.

siswa khususnya siswa di sekolah menengah atas, di mana mereka sudah mampu dalam menganalisis dan berpikir kritis. Informasi yang mereka dapatkan hendaknya jangan terbatas dengan materi yang telah tersedia di dalam buku teks saja. Menurut Heychael dalam Maman (2018, hlm. 98) bahwa buku teks sejarah ialah sebagai bentuk dari implementasi pewacanaan identitas nasional dan teks-teks yang terdapat di dalamnya bisa dipastikan mengakomodir sebagian dari pengetahuan yang utuh dan menyisihkan bagian pengetahuan lainnya. Begitu juga buku teks yang digunakan di sekolah, ideologi kenegaraan dengan perantara kebijakan pendidikan dan kebijakan kurikulum sangat mempengaruhi buku teks tersebut. Seperti halnya pembelajaran tentang ideologi marxisme ataupun komunisme yang di larang pada masa pemerintahan orde baru. Materi tersebut dianggap sebagai sesuatu yang kontroversial.

Purwanto (2009) membedakan sejarah kontroversial menjadi dua bagian yaitu sejarah kontrovesial politis dan sejarah kontroversial keilmuan. Ia menyebutkan bahwa sejarah kontroversial politis mengacu pada azas kepentingan dari pemerintah. Hal ini dilakukan sebagai upaya dalam mempertahankan kekuasaannya. Berbeda halnya dengan sejarah kontroversial keilmuan yang justru bersangkutan dengan tidak mampunya secara historiografis maupun metodologis dalam melaksanakan konstruksi begitupun rekonstruksi tentang masa lalu terkait dengan subjektifitas yang lemah dan pemaknaan terhadadp pembelajaran sejarah. Kontroversi dalam materi pembelajaran sejarah sangat kental pada masa pemerintahan Orde Baru, dimana peran Soekarno dan hasil ide, gagasan, serta pemikirannya seperti tersamarkan bahkan beberapa bagian dilarang termasuk materi yang berkaitan dengan nasakom. Namun seiring perkembangan politik dan pemegang kekuasaan, hal tersebut sedikit mengalami perubahan meskipun memori kolektif yang telah terbentuk sulit untuk dihilangkan.

Berikut ini adalah materi yang berkaitan dengan nasakom yang terdapat pada buku teks sejarah kelas XI semester 1 (Sadirman A.M. dan Lestringsih, 2017, hlm 203):

Dalam rangka merealisasikan gagasan tentang persatuan itu, Ir. Sukarno ingin membentuk wadah persatuan dengan memadukan aliran nasionalisme, Islam dan marxisme, sehingga merupakan kekuatan moral dan nasionalisme yang kokoh. Gagasan tentang persatuan dan kerja sama antarorganisasi itu sudah lama didengungkan oleh PI. Bahkan "persatuan" menjadi salah satu asas perjuangan PI. Tahun 1926 Moh. Hatta dengan tegas menyatakan perlunya diciptakan "blok nasional" yang terdiri atas partai-partai politik (organisasi-organisasi pergerakan), baik yang berbasis komunis maupun yang nasionalis, (baik yang agamis maupun yang sekuler), guna menghadapi penjajahan pemerintah Hindia Belanda. Namun sayangnya pada tahun 1926 dan awal tahun 1927 PKI dengan ambisinya melakukan gerakan sendiri melawan kekuasaan Belanda dan akhirnya dapat dihancurkan oleh Belanda.

Kemudian pada buku sejarah kelas XII semester 1 terdapat sedikit materi yang berkaitan dengan nasakom seperti yang terlihat di bawah ini:

Soekarno yakin bahwa gerakan komunisme bisa dikendalikan, sedangkan Hatta sangat menentang gerakan komunisme dan menganggapnya sebagai bahaya laten yang harus dilenyapkan. Presiden Soekarno kemudian berusaha mendesak para tokoh partai PNI, Masyumi, NU dan PSII agar mau menerima wakil PKI atau pun simpatisannya untuk duduk dalam kabinet. Namun kehendak Presiden Soekarno tersebut tidak bisa diterima oleh tokohtokoh dari ketiga partai tersebut (Sadirman A.M. dan Lestringsih, 2017, hlm. 58-59).

Dapat dilihat bahwa dengan hanya mengacu pada buku teks, bukan tidak mungkin justru akan menimbulkan salah persepsi pada peserta didik. Maka sangat diperlukan kekayaan sumber informasi yang harus digali baik guru maupun siswa.

Pembelajaran tentang ideologi marxisme yang merupakan bagian dari konsep nasakom bukan berarti untuk menumbuhkan kembali bibit ideologi tersebut kepada anak didik akan tetapi menjadi pembelajaran bagi peserta didik tentang Soekarno dan pemikirannya. Serta menjadi pelurusanfakta sejarah di manaSoekarno disalah artikan sebagai seorang komunis padahal ia sendiri telah menentang hal tersebut. Telah diungkapkan sebelumnya bahwa Soekarno bukan seorang komunisme, ia justru berusaha untuk mempersatukan ideologi-ideologi tersebut untuk kepentingan bangsa agar tidak terjadi perpecahan meskipun ideologi komunisme dianggap bertentangan dengan ideologi bangsa Indonesia.

\section{SIMPULAN}

Pembelajaran sejarah hendaknya bukan sarana untuk menjustifikasi suatu fakta ataupun peristiwa dengan kaitan benar atau salahnya peristiwa sejarah tersebut namun lebih berorientasi pada penanaman nilai yang dapat diserap oleh siswa dari peritiwa tersebut. Dengan referensi yang lebih kaya maka siswa diharapkan dapat memahami bahwa setiap ideologi memiliki kekurangan dan kelebihan. Nasakom yang bukan sekedar konsep Soekarno namun juga sebuah ideologi yang berusaha di diterapkan meskipun hal tersebut mengalami 
kegagalan. Ideologi nasakom khususnya yang dianggap ideologi kiri, meskipun dianggap berbahaya dan dapat menghancurkan bangsa namun pada dasarnya bukanlah ideologinya yang berbahaya akan tetapi oknum yang menyelewengkan ideologi tersebutlah yang berbahaya (Winata, 2017).

\section{REFERENSI}

Abdurakhman, Arif. P, Linda. S., dan Susanto. Z (Kontributor). (2015). Sejarah indonesia untuk sma/ma/smk/mak kelas xii semester $i$. Jakarta: Pusat Kurikulum dan Perbukuan, Balitbang, Kemendikbud.

Adams, C. (2018). Bung karno penyambung lidah rakyat indonesia (edisi revisi). Jakarta: Yayasan Bung Karno dan Yogyakarta: Media Pressindo.

Cenne, A.A. (2016). Pemikiran politik soekarno tentang nasakom rentang 1959-1966. Skripsi Unhas, tidak diterbitkan.

Dahm, B. (1969). Sukarno and the struggle for indonesia independence. Ithaca and London: Cornell University Press.

Feith, H. (1995). Soekarno dan militer dalam demokrasi terpimpin. Jakarta: Pustaka Sinar Harapan.

Feith, H dan L. Castles. ed. (1988). Pengantar dalam pemikiran politik indonesia 1945-1965. Jakarta: LP3ES , pp. xiI-Ixvii.

Hasan, S.H. (2012). Pendidikan sejarah untuk memperkuat pendidikan karakter. Jurnal Paramita, V (I), 81-95. ISSN: 0854-0039.

Kasenda, P. (2014). Sukarno, marxisme \& leninisme:akar pemikiran kiri dan revolusi indonesia. Depok: Komunitas Bambu.
Maman, M. S. (2018). Identitas nasional dalam buku teks pelajaran sejarah sma. HISTORIA: Jurnal Pendidik dan Peneliti Sejarah, 1(2), 97-104.

Pamudyaningtyas, B.M. (2011). Gagasan soekarno tentang nasakom dan sosialisasinya pada tahun 1960-1965. Tesis Universitas Sanata Dharma. Tidak diterbitkan

Purwanto, B. (2009). Gagalnya historiografi indonesiasentris. Yogyakarta: Ombak

Sadirman A.M. dan Lestringsih, A.D (Kontributor). (2017). Sejarah indonesia untuk sma/ma/smk/mak kelas xi semester $i$. Jakarta: Pusat Kurikulum dan Perbukuan, Balitbang, Kemendikbud.

Soekarno. (1964). Di bawah bendera revolusi, jilid I. (Cetakan Ketiga). Jakarta: Panitia Penerbit Di Bawah Bendera Revolusi.

Soekarno. (1983). Indonesia menggugat. Jakarta: Departemen Penerangan Republik Indonesia.

Tabroni, R. (2015). Komunikasi politik soekarno mengguncang dunia lewat pidato dan tulisan. Bandung: Simbiosa Rekatama Media.

Winata, L dan Purwaningsih, S.M. (2017). Nasakom sebagai ideologi negara 1956-1965. Jurnal Avatara, 5(3), 728-737.

Yanlua, M.A. (2017). Studi perbandingan pemikiran Nasakom bung karno dan piagam madinah dalam konteks indonesia. Skripsi UIN Alauddin Makasar: Tidak diterbitkan 